\title{
REDD+ policy making in Nepal: toward state-centric, polycentric, or market-oriented governance?
}

\author{
Bryan R. Bushlev ${ }^{1,2}$
}

\begin{abstract}
Over the past 40 years, Nepal has become renowned for its community-based forestry policies, initiatives, and institutions, characterized by local autonomy in decisions about forest management and use and a gradual shift toward more inclusive national policy processes. In recent years, the government, international nongovernmental organizations (NGOs), donors, and some civil society organizations have instigated policy and piloting initiatives for an international climate change mitigation scheme known as "reducing emissions from deforestation and forest degradation and enhancement of forest carbon stocks in developing countries" (REDD+). Although many people see REDD+ as a means of bolstering forest conservation efforts and enhancing rural livelihoods, its broader implications for decentralized forest governance in Nepal and elsewhere remain uncertain and contested. Using policy network analysis and theories of polycentric and network governance, I examined influence, inclusiveness, and deliberation among actors involved in REDD+ policy making in Nepal. Data were collected between June and December 2011 through a survey of 34 organizations from government, civil society, educational and research institutions, international NGOs and donors, and the private sector. I investigated whether policy processes and the configurations of actors involved reflect state-centric, market-oriented, or polycentric governance, and I discuss the implications for decentralized forest governance in general and for the implementation of REDD+ in particular. Results indicate that REDD+ policy making is dominated by a "development triangle", a tripartite coalition of key government actors, external organizations (international NGOs and donors), and select civil society organizations. As a result, the views and interests of other important stakeholders have been marginalized, threatening recentralized forest governance and hampering the effective implementation of REDD+ in Nepal.
\end{abstract}

Key Words: climate change; conservation; decentralization; forest governance; policy networks; South Asia

\section{INTRODUCTION}

Reducing emissions from deforestation and forest degradation and enhancement of forest carbon stocks in developing countries (REDD+) has strong implications for forest governance worldwide. REDD+ is an emerging market-based mechanism designed to curb greenhouse gas emissions through performancebased payments for the protection and sustainable management of forests. Some stakeholders involved in REDD+ believe that it will inject renewed vigor, transparency, and accountability into forest governance and promote decentralized and inclusive modes of governance, considered necessary for forest conservation and reforestation (Springate-Baginski and Wollenberg 2010). Others note its potential to recentralize governance and threaten biodiversity by ignoring social and ecological safeguards, increasing the value of forests to governments (and thus incentives to regain control over them), and promoting more technobureaucratic, carbon-focused approaches to forest management, thereby undermining community rights and benefits, incentives to protect the forest, and reductions in forest-carbon emissions (Phelps et al. 2010). Yet others claim that mechanisms such as REDD+ constitute a distinct form of forest governance shaped by emerging markets, in which certain actors and solutions are favored over others, thus determining the engagement of and outcomes for different stakeholders (Thompson et al. 2011).

Employing the lens of network governance and the tools of policy network analysis, and using Nepal as a case study, I examine REDD+ in the context of the ongoing transition from statecentric to more polycentric and market-oriented modes of governance. I speculate about the impact REDD+ is having or will have on this transition by addressing the following overarching research question: How inclusive and deliberative is the REDD+ policy-making process? This question is addressed through two secondary (operative) research questions: Which actors and groups of actors or sectors are most dominant and which are most marginalized in the policy-making process? To what extent do actors and groups of actors such as government, civil society organizations (CSOs), educational/research institutions, international nongovernmental organizations (INGOs), donors, and private sector organizations engage in information sharing and collaboration with one another? I draw on my analysis to discuss which of three broad types of governance REDD+ policy making in Nepal most resembles: topdown, government-led, state-centric governance; marketoriented governance driven by market influences and actors; or polycentric governance characterized by multiple nodes of authority and decentralization and/or deliberative decision making. I consider which actors and groups dominate the policy process, as shown through network relations. Finally, I reflect on the implications of my findings for the current system of decentralized forest governance in Nepal.

Forest governance has undergone a pronounced transition over the past few decades. It has developed from a state-centric paradigm toward a polycentric one involving new actors and legal and administrative decentralization (Ribot et al. 2006, Tyler 2006, Springate-Baginski and Blaikie 2007, Agrawal and Ostrom 2008, Agrawal et al. 2008). Once largely the purview of colonial administrations and the state, the management, use, and benefits of forests are increasingly shared by a range of stakeholders from multiple sectors, including civil society, private companies, and local communities, and at multiple scales, from local to international (Agrawal et al. 2008). Simultaneously, market actors and incentives are increasingly affecting decisions about forest management and use (Cashore 2002, Agrawal et al. 2008). Nepal's forestry sector and community forestry program exemplify this 
transition, with more than 30 years of decentralization, significant deliberation, and increasing engagement with markets.

It is widely held that decentralization initiatives can enhance efficiency and equity of forest management, as well as the ability of governments to effectively respond to local people's needs, demands, and aspirations (Ribot et al. 2006, Larson and Soto 2008). There is also evidence that decentralization can promote more sustainable forest management and enhance ecological outcomes (Gibson et al. 2000, Springate-Baginski and Blaikie 2007). For decentralization to be truly transformative and promote meaningful change for local communities and the protection of their forests, it must come from below, driven by the demands and needs of grassroots actors (Larson and Soto 2008). Thus, rather than being solely an administrative act, decentralization is a political process often fraught with contestation and power struggles (Ribot et al. 2006).

Some argue that by focusing on local socioeconomic and ecological objectives such as tenure reform, REDD+ could further stimulate decentralized forest governance (Angelsen 2008). However, experience in various countries reveals that forest decentralization does not always meet its stated objectives or implicit goals, especially in terms of strengthening local resource management and use rights (Ribot et al. 2006). Decentralization initiatives are frequently accompanied (and undermined) by restrictions or limitations imposed by governments seeking to maximize their own efficiency, management objectives, and benefits, while not fully devolving decision making and management authority to local bodies (Ribot et al. 2006). A further challenge of decentralization is its inability to avoid the subversion of democratic processes by more powerful actors at multiple levels (Lane 2003). In Nepal and elsewhere, there is tension between formal decentralization initiatives and informal, often covert, efforts to recentralize or maintain power and control over critical financial, political, and natural resources (Dahal 2003, Ribot et al. 2006, Ojha 2008, Sunam et al. 2013). There are concerns that REDD+ might reinforce these recentralizing tendencies in forest governance (Phelps et al. 2010). Moreover, decentralization does not guarantee that local governance and management of forests will be transparent or equitable. There have been numerous cases in Nepal of exclusion, elite capture, corruption, and collusion involving community leaders and external actors (Dahal 2003, Iversen et al. 2006, Thoms 2008).

\section{DECENTRALIZATION, COMMUNITY FORESTRY, AND REDD+ IN NEPAL}

Nepal's community forestry program grew out of efforts to mitigate the perceived threat of rampant deforestation and soil erosion in Nepal's Middle Hills during the 1970s (e.g., Guthman 1997) by enlisting local communities in conservation efforts. Its evolution has been marked by a steady expansion in donor funding and technical support for community-based forest management initiatives (1980s onward); formulation of supportive laws, policies, and government institutions (late 1980s to mid-1990s); increased allocation of state forest lands to communities for their management and use (mid-1990s to mid-2000s); a burgeoning of civil society groups concerned with promoting social and economic rights and opportunities for local communities with respect to forests (mid-1990s onward); and a growing emphasis on marketing of products and services from community-managed forests (late 1990s onward).

Today, Nepal's community forestry program is one of the most extensive and widely studied systems of community-based natural resource management, involving more than 17,685 forest user groups, comprising almost 2.2 million households or nearly $35 \%$ of Nepal's population, which collectively manage approximately 1.65 million ha $(\sim 25 \%)$ of Nepal's forested area (Kanel 2008 , Department of Forests 2011). It engages actors from government, civil society, educational and research institutions, donor organizations, and the private sector in forest governance. Community forestry has promoted the recovery of degraded forests in many areas and supported the socioeconomic development of rural communities (Nagendra 2007, Pokharel et al. 2007, Kanel and Dahal 2008, Pandit and Bevilacqua 2011). This is largely due to the efforts and hard-won achievements of forest-dependent communities and their advocates (Britt 2010). Despite these advances, community forestry has met with some resistance by government agents attempting to curtail local rights, autonomy, and benefits in various ways (Ojha 2008). Over the past decade, declarations of new protected areas, proposals to raise taxes on products from community forests, bans on harvesting live trees, and repeated threats to revise the Forest Act of 1993 to curtail local autonomy provide some evidence of the government's recentralizing tendencies (Sunam et al. 2013).

Threats to forests remain prevalent in Nepal, particularly in the subtropical Terai and Churia Hills regions (Devkota 2010). Allegations of corruption have surfaced within Nepal's forestry sector at all levels, from the Cabinet to the communities, along with claims that this corruption has led to a spree in illegal timber harvesting and trade, resulting in increased degradation and deforestation in both government-managed and communitymanaged forests (Devkota 2010). Curbing deforestation and forest degradation remains an elusive goal in many areas (Pokharel and Byrne 2009), posing significant challenges for REDD+ policy-making and implementation (Paudel et al. 2013).

Key government, civil society, and international actors have taken an active interest in REDD+ in Nepal in the hope that it could help address ongoing corruption and deforestation and bring financial benefits for communities and other stakeholders. Since 2008, the World Bank's Forest Carbon Partnership Facility and other donors have provided financial and technical support to the government to develop its Readiness Preparation Proposal (R$\mathrm{PP})$, which defines key components of a technical, institutional, and policy framework for REDD+. Following approval of the RPP in October 2010, the government moved to develop a national strategy for REDD+ implementation after 2013. In addition, donor-sponsored pilot projects have been introduced to demonstrate the social and technical viability of REDD + at the sub-national level; they aim to develop local implementation capacity and to set baselines for measuring the socioeconomic, ecological, and forest-carbon impacts of REDD+. These projects have worked closely with communities to enhance their technical ability to measure and record carbon stocks in their forests; to devise effective and equitable benefit-sharing schemes; and to inform stakeholders about climate change and the opportunities, risks, and challenges associated with carbon trading (Bushley and Khatri 2011). All of these efforts aim to enhance Nepal's 
"REDD+ readiness", or its capacity to effectively engage in REDD+ during the subsequent implementation phase.

\section{THEORETICAL BASIS AND CONCEPTUAL FRAMEWORK}

Two concepts are integral to understanding the governance of forests and other natural resources under conditions of decentralization: polycentricity and deliberative governance. Fundamentally, polycentricity means the presence of multiple, independent nodes or "centers" of authority in the provision of public and/or private goods and services (Ostrom 2010). We can achieve a more robust, cross-scale understanding of polycentricity by viewing it as comprising both vertical and horizontal dimensions: decentralization and deliberative governance, respectively. Decentralization denotes a shift in administrative, fiscal, and/or decision-making authority from larger (e.g., national) to smaller (e.g., state, district, or community) geographical scales (Ribot et al. 2006). It can, but does not always, result in polycentric governance structures; this depends largely on the extent of deliberative governance (Andersson and Ostrom 2008, Andersson et al. 2012). Deliberative governance or "deliberative democracy" embodies the idea that more equitable and sustainable public policy decisions will be achieved through open dialog and debate among diverse actors from different sectors (Dryzek 2010). There is some overlap between the two: decentralization can involve devolution of authority from government entities to actors in other sectors and deliberation can occur across administrative scales. Thus, decentralization promotes greater autonomy in local institutional structures, whereas deliberative governance facilitates inclusion and interactions among a wider array of actors, views, and interests across sectors and scales. These two interlinked processes reinforce each other and are essential to strong, pluralistic, and cohesive governance structures and institutions (Andersson and Ostrom 2008, Andersson et al. 2012).

Three models of governance are commonly applied to the management and decentralization of forests and other natural resources and ecosystems (Fig. 1). In the first, state-centric governance, government controls decisions concerning the management and use of forests and their resources and reaps most of the benefits. The second, market-oriented governance, represents a mixed approach that relies heavily on economic incentives from private sector investments to promote benefits for forest managers while pursuing specific ecological and/or social goals and also involving state and/or civil society actors (Cashore 2002). The third, polycentric governance, challenges the notion that governments or markets are the best stewards of forests, noting the important role played by local institutions (Ostrom 2009, 2010). It implies the existence of multiple nodes of power whereby the formulation and execution of decisions and policies are shared among diverse actors from different sectors (e.g., government, civil society, the private sector) and at different administrative levels (e.g., national to local; Ostrom 2009).

A fourth, distinct conceptualization known as network governance is increasingly being employed to study policymaking processes at global, national, and local levels (Kenis and Schneider 1991, Perkins and Court 2005; Fig. 1). Like polycentric governance, network governance involves multiple, dispersed points of decision making. However, whereas polycentric governance focuses largely on participation, interests, sources of authority, and overlapping institutions (shared rules and norms) among autonomous actors, network governance is primarily concerned with cooperation and conflict among actors, including flows of information and resources. Thus, network governance focuses on relations among actors and groups of actors as key determinants of policy and governance outcomes and is concerned with the structure and performance of the network as a whole (Carlsson and Sandström 2008). Dedeurwaerdere (2005:2) states that network governance strives to "take into account the increasing importance of NGOs, the private sector, scientific networks and international institutions ... to create a synergy between different competences and sources of knowledge in order to deal with complex and interlinked problems." It contrasts with more elitist approaches such as the "iron triangle", often used to describe issue-based politics in the United States, which is characterized by interactions among a small, exclusive set of actors from the government bureaucracy, legislature, and powerful interest groups (Kenis and Schneider 1991).

Fig. 1. Conceptual framework of modes and processes of forest governance. The three main sectors are state, market, and civil society, and the models of governance are state-centric, marketoriented, polycentric, and network. These occur across scales from the national to the community level, along with the paired processes of decentralization and deliberation. Nodes and solid lines represent network governance; dashed arrows represent the processes of decentralization and deliberation.

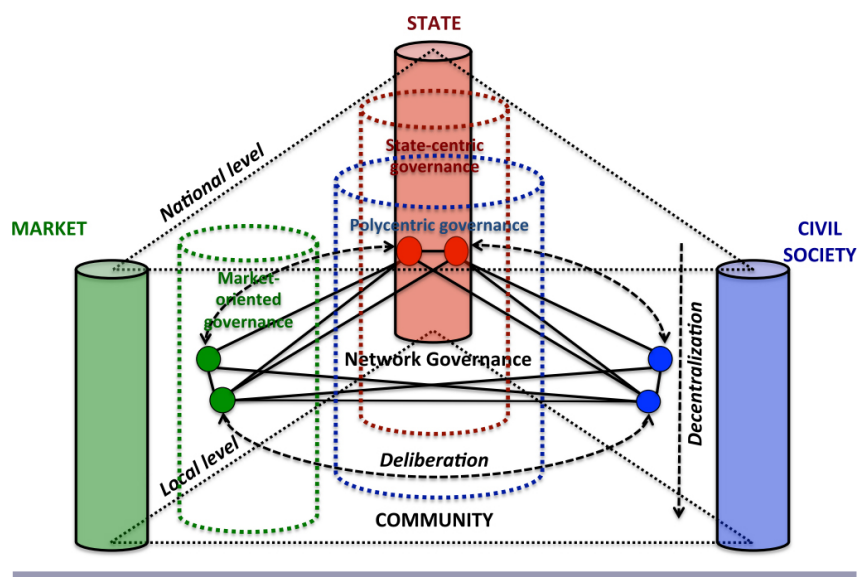

Network governance can be conceptualized through policy networks, or sets of specific relations among policy actors. According to Kenis and Schneider (1991), policy networks represent new hybrid forms of political governance and resource mobilization, marked by an altered relationship between state and society, in which decision making and program formulation and implementation are shared among various public and private actors. In the context of REDD+ policy making, this means that organizational actors from different sectors are expected to play an active role in key policy decisions through joint involvement in policy forums, e.g., multi-stakeholder dialogs, working groups, and as members of legislative and executive bodies. According to Dryzek (2010:124-125), "Networks are polycentric... while inequalities may exist within networks, they are not formally constituted as hierarchies... [but] a network can be more or less 
Table 1. Definitions, meanings, and uses of measures employed in analyzing REDD+ policy networks in Nepal.

\begin{tabular}{|c|c|c|c|}
\hline $\begin{array}{l}\text { Social network } \\
\text { analysis measure }\end{array}$ & Definition & Meaning in practice & What it measures \\
\hline In-degree centrality & Sum of an actor's incoming ties $\dagger$ & $\begin{array}{l}\text { Level of activity or popularity of a } \\
\text { given actor as identified by others }\end{array}$ & $\begin{array}{l}\text { Level of perceived influence and } \\
\text { involvement in information } \\
\text { exchange/collaboration }\end{array}$ \\
\hline $\begin{array}{l}\text { In-degree } \\
\text { centralization }\end{array}$ & $\begin{array}{l}\text { Degree of inequality or variance in a network } \\
\text { as a percentage of that of a perfect star } \\
\text { (completely centralized) network of the same } \\
\text { sizet }\end{array}$ & $\begin{array}{l}\text { Extent to which nodes are connected } \\
\text { to one central actor in a network via } \\
\text { incoming ties }\end{array}$ & $\begin{array}{l}\text { Concentration of power in } \\
\text { information exchange/collaboration }\end{array}$ \\
\hline $\begin{array}{l}\text { Betweenness } \\
\text { centrality }\end{array}$ & $\begin{array}{l}\text { Number of times an actor connects pairs of } \\
\text { other actors who otherwise could not reach one } \\
\text { another } \dagger\end{array}$ & $\begin{array}{l}\text { Individual actor's potential to } \\
\text { control relations or flows of } \\
\text { information and resources between } \\
\text { other actors who it connects }\end{array}$ & $\begin{array}{l}\text { Degree of "brokerage" in (control } \\
\text { over) information exchange/ } \\
\text { collaboration }\end{array}$ \\
\hline $\begin{array}{l}\text { Betweenness } \\
\text { centralization }\end{array}$ & $\begin{array}{l}\text { Degree of inequality or concentration in the } \\
\text { distribution of betweenness centralities among } \\
\text { actors relative to that of a perfect star } \\
\text { (completely centralized) networkt }\end{array}$ & $\begin{array}{l}\text { Average difference in centrality } \\
\text { between the most central node and } \\
\text { all others } \S\end{array}$ & $\begin{array}{l}\text { Concentration of control of } \\
\text { information exchange/collaboration }\end{array}$ \\
\hline Core-periphery ratio & $\begin{array}{l}\text { Number of actors found in the core (those with } \\
\text { high density of mutual ties) vs. the periphery } \\
\text { (those with low density of mutual ties) } t\end{array}$ & $\begin{array}{l}\text { Proportion of those actors who } \\
\text { interact most frequently with each } \\
\text { other (core) to those who interact } \\
\text { seldom with each other (periphery) }\end{array}$ & $\begin{array}{l}\text { Proportion of actors strongly/ } \\
\text { weakly involved in information } \\
\text { exchange/collaboration (core actors } \\
\text { as a percentage of all actors) }\end{array}$ \\
\hline (Group) Homophily & $\begin{array}{l}\text { Extent to which two actors (or groups) who } \\
\text { share some attribute form social ties with each } \\
\text { othert }\end{array}$ & $\begin{array}{l}\text { Degree of interaction among like } \\
\text { actors (or groups) }\end{array}$ & $\begin{array}{l}\text { Extent of information exchange/ } \\
\text { collaboration (i.e., deliberation) } \\
\text { within and among actor groups }\end{array}$ \\
\hline \multicolumn{4}{|c|}{$\begin{array}{l}\text { †Source: Hawe et al. (2004). } \\
\text { \$Source: Hanneman and Riddle (2005). } \\
\text { §Source: White and Borgatti (1994). }\end{array}$} \\
\hline
\end{tabular}

inclusive of those affected by a decision, as well as more or less deliberative when it comes to the terms of their inclusion." We should also acknowledge political economy critiques that question more normative conceptualizations of policy networks and reveal how hierarchical relationships can be embedded in supposedly horizontal networks, affecting their nature and efficacy (Davies 2012). Using Nepal as a case study, I examine the unevenness in REDD+ policy networks and its broader implications for decentralized forest governance.

\section{METHODS}

Social network analysis (SNA) is a useful tool for studying relationships, views, and flows of information and resources among actors engaged in social processes (Wasserman and Faust 1994, Scott 2004). It has been employed to study social-ecological systems, natural resource regimes, and political systems in various contexts and at multiple scales (Bodin and Prell 2011), including functions such as sharing of information, resources, perspectives, and authority among diverse individuals and organizations, and associated environmental policy processes at national and international scales (Kenis and Schneider 1991, Dedeurwaerdere 2007, Crona and Hubacek 2010). SNA can also help determine whether information exchange and collaborative ties (i.e., characteristics of the policy network) reflect a hierarchical (statecentric) or market-oriented model (Kenis and Schneider 1991). I investigate the national REDD+ policy network in Nepal using SNA measures to assess the degree of polycentricity and, to a certain extent, deliberation in a governance regime or policy process.
Box 1: Survey questions used to analyze network variables.

Perceived influence: Which organizations stand out as being especially influential in the development of domestic REDD+ policies?

Information exchange: With which organizations does [your organization] regularly or routinely discuss and exchange information about REDD+ policy matters?

Collaboration: With which organizations does [your organization] regularly collaborate on REDD+-related issues and activities?

To investigate relations among actors, one perception variable (perceived influence, which is a measure of reputational power) and two relational variables (information exchange and collaboration) were used for organizations active in REDD+ policy making. The relevant survey questions for each perception or relation variable are presented in Box 1. In the resulting networks, nodes represent the actors (organizations) that participate in the REDD+ policy domain, and ties (lines between nodes) represent specific perceptions or relations (Fig. 2). For each variable, I examine several network measures (see Table 1 for specific measures and their definitions, meanings, and uses). These results are then combined and compared across the three network variables to assess which groups and actors have the most influence and involvement overall. 
Fig. 2. Organizations in the REDD+ policy arena in Nepal that regularly discuss and exchange information (a) and collaborate (b) with each other on REDD+ issues. $N=34$ organizations. The size of nodes indicates degree centrality, i.e., the number of incoming and outgoing ties. Circular nodes indicate actors in the core; square nodes indicate actors in the periphery. Node color denotes organization type, as indicated in the key. Numbers accompanying each node correspond to the organization identification numbers (Table 3 ).

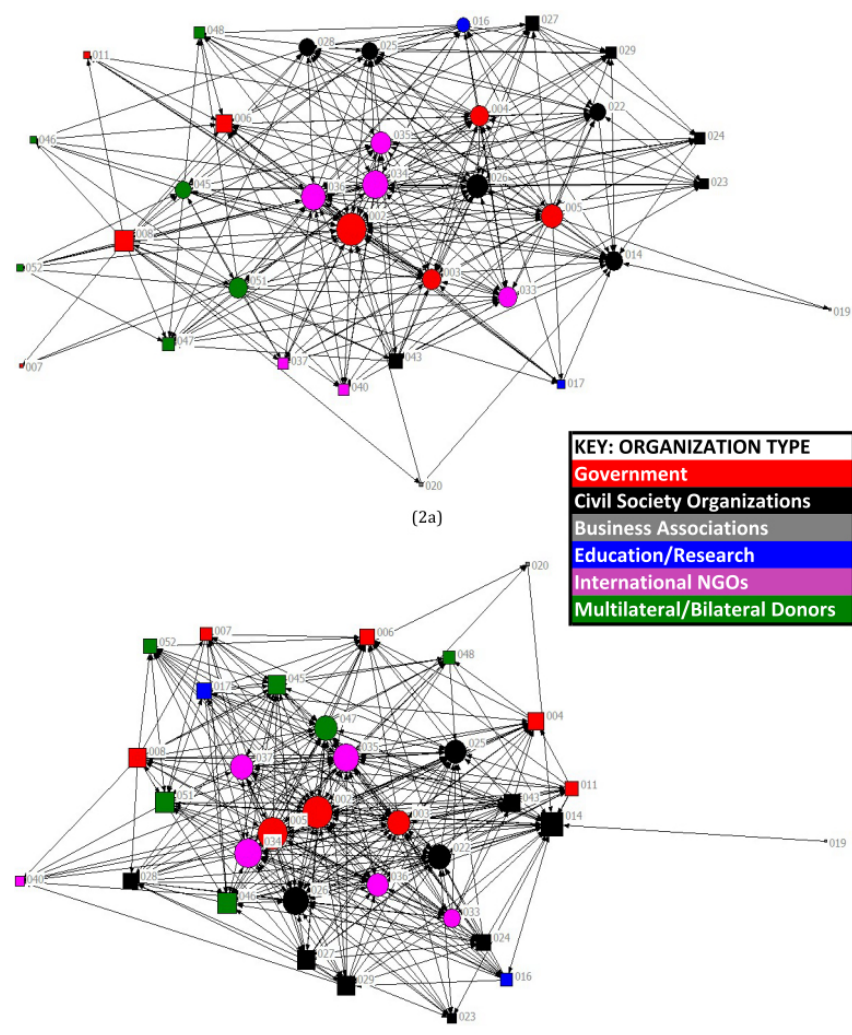

(2b)

The current analysis is based on a detailed survey of 34 organizations (policy actors) involved in REDD+ policy making in Nepal, which included relational questions (i.e., about interactions among policy actors), conducted between February and December 2011. Initially, a panel of experts working in Nepal's forestry sector identified 53 organizations relevant to REDD+. However, we omitted 19 of these organizations from the survey based on three factors: lack of direct involvement in REDD+ policy making, i.e., they had no formal role in policy deliberations, decision-making bodies, or projects, which was ascertained through preliminary discussions and semi-structured interviews with these organizations $(N=14)$; redundancy with other organizations, i.e., their constituent departments or divisions were included in the survey $(N=1)$; or difficulty in securing an appointment $(N=4)$. Thus, 34 organizations (actors) participated in the survey (see Table 2 and Appendix 1) and were included in the analysis of the three network variables. Actors constitute six distinct groups based on their sector (Table 3): (1) government organizations (ministries, departments); (2) educational/research institutions (universities and institutes); (3) national NGOs/CSOs (both membership and non-membership, including professional associations); (4) business associations (representing private companies in the forest product and general business sector); (5) international NGOs; and (6) multi-lateral/ bilateral donor agencies (multi-lateral development banks, United Nations, country aid agencies).

The network variables were analyzed using social network analysis software (UCINET) and accompanying visualization software (NetDraw; Borgatti et al. 2002). The analysis incorporates measures at both node (actor) and network levels for each of the three network variables. Node-level measures are also aggregated to assess the relative importance of the groups for each network variable. I analyzed each of the two operative research questions as described next.

Which actors and groups of actors are most dominant and which are most marginalized in the policy-making process? Inclusiveness is indicated by the most dominant and marginalized actors and groups of actors in the policy network, as measured by in-degree centrality, betweenness centrality, and the core-periphery ratio. In-degree and betweenness centrality indicate the frequency of incoming/connecting ties. The core-periphery ratio measures those actors in the core of the network (i.e., with many mutual interactions) vs. those in the periphery (i.e., with few mutual interactions).

To what extent do groups of actors engage in information sharing and collaboration (i.e., deliberation) with one another? Deliberation is reflected by the density of communication and collaboration among and within distinct actor groups, illustrated by network measures such as in-degree/betweenness centralization and homophily. Centralization reveals the extent to which interactions are controlled or shaped by the most central actor (and other influential intermediaries). In highly centralized networks, key actors can easily manipulate flows of information or resources. Such networks can also break down easily if the functioning of these actors is compromised. Homophily reveals the propensity of groups to interact internally with their own members.

\section{RESULTS}

The results are presented for each research question and for each of the three network variables: perceived influence, information exchange, and collaboration. The number codes, names, abbreviations, and network measures for each organizational actor are listed in Table 2.

\section{Dominant and marginal groups and actors in the REDD+ policy domain}

\section{Perceived influence}

The groups (and actors) identified as having the most reputational power (perceived influence) in REDD+ policy making are government (REDD Cell, DoF, MoEnv, DFRS, DNPWC), CSOs (NEFIN, FECOFUN, FA), and, to a lesser extent, INGOs (WWF, ICIMOD). Of the most influential actors, five (50\%) are government entities (three of which are divisions of the Ministry of Forests and Soil Conservation), three are CSOs, and two are INGOs. This is reflected in the in-degree centrality values for perceived influence (Table 2). Conversely, actors perceived as least 
Table 2. Perceived influence, information exchange, and collaboration of individual actors.

\begin{tabular}{|c|c|c|c|c|c|c|c|c|c|}
\hline \multirow{2}{*}{\multicolumn{3}{|c|}{ Type of organization (actor group) }} & \multicolumn{7}{|c|}{ Network variable } \\
\hline & & & \multirow{2}{*}{$\begin{array}{l}\begin{array}{l}\text { Perceived } \\
\text { influence }\end{array} \\
\begin{array}{l}\text { In-degree } \\
\text { centrality }\end{array}\end{array}$} & \multicolumn{2}{|c|}{ Information exchange } & \multicolumn{2}{|c|}{ Collaboration } & \multicolumn{2}{|c|}{$\begin{array}{l}\text { Information exchange } \\
\text { and collaboration }\end{array}$} \\
\hline ID $(N=34)$ & Name & Abbreviation & & $\begin{array}{l}\text { In-degree } \\
\text { centrality }\end{array}$ & $\begin{array}{l}\text { Between- } \\
\text { ness } \\
\text { centrality }\end{array}$ & $\begin{array}{l}\text { In-degree } \\
\text { centrality }\end{array}$ & $\begin{array}{c}\text { Between- } \\
\text { ness } \\
\text { centrality }\end{array}$ & $\begin{array}{c}\text { Average } \\
\text { in-degree } \\
\text { centrality } \dagger\end{array}$ & $\begin{array}{c}\text { Average } \\
\text { betweenness } \\
\text { centrality }\end{array}$ \\
\hline \multicolumn{10}{|l|}{ Government } \\
\hline 002 & REDD Forestry and Climate Change Cell & REDD Cell & $33 \ddagger$ & 31 & 242.31 & 28 & 157.73 & 29.50 & 200.02 \\
\hline 003 & Department of Forests & DoF & 30 & 17 & 10.19 & 19 & 24.78 & 18.00 & 17.49 \\
\hline 004 & Department of Forest Research and Survey & DFRS & 28 & 14 & 63.77 & 14 & 4.40 & 14.00 & 34.08 \\
\hline 005 & Department of National Parks and Wildlife Conservation & DNPWC & 22 & 7 & 75.83 & 10 & 46.52 & 8.50 & 61.17 \\
\hline 006 & Ministry of Environment & MoEnv & 28 & 15 & 14.33 & 15 & 0.00 & 15.00 & 7.16 \\
\hline 007 & Ministry of Agriculture & MoAgr & 12 & 3 & 0.05 & 5 & 0.73 & 4.00 & 0.39 \\
\hline 008 & Ministry of Local Development & MoLD & 12 & 4 & 62.45 & 5 & 11.74 & 4.50 & 37.09 \\
\hline 011 & $\begin{array}{c}\text { Department of Soil Conservation and Watershed } \\
\text { Management }\end{array}$ & DSCWM & 10 & 3 & 0.22 & 4 & 1.94 & 3.50 & 1.08 \\
\hline \multicolumn{10}{|l|}{ Civil society } \\
\hline 022 & Nepal Foresters' Association & NFA & 18 & 11 & 10.80 & 16 & 33.93 & 13.50 & 22.37 \\
\hline 023 & Rangers' Association Nepal & RAN & 15 & 8 & 2.54 & 8 & 0.00 & 8.00 & 1.27 \\
\hline 024 & Community-based Forestry Supporters' Network & COFSUN & 11 & 6 & 1.84 & 7 & 1.84 & 6.50 & 1.84 \\
\hline 025 & Nepal Federation of Indigenous Nationalities & NEFIN & 29 & 16 & 5.64 & 19 & 27.77 & 17.50 & 16.71 \\
\hline 026 & Federation of Community Forest Users Nepal & FECOFUN & 28 & 19 & 82.96 & 22 & 67.00 & 20.50 & 74.98 \\
\hline 027 & Association of Collaborative Forest Users Nepal & ACOFUN & 9 & 4 & 4.89 & 7 & 4.52 & 5.50 & 4.70 \\
\hline 028 & Dalit Alliance for Natural Resources Nepal & DANAR & 9 & 11 & 23.87 & 14 & 1.94 & 12.50 & 12.90 \\
\hline 029 & $\begin{array}{c}\text { Himalayan Grassroots Women's Natural Resource } \\
\text { Management Association }\end{array}$ & HIMAWANTI & 8 & 7 & 1.95 & 9 & 5.39 & 8.00 & 3.67 \\
\hline 014 & ForestAction Nepal & FA & 21 & 16 & 62.99 & 20 & 69.48 & 18.00 & 66.23 \\
\hline 043 & NGO Group on Climate Change & NGOGCC & 6 & 4 & 1.17 & 7 & 3.98 & 5.50 & 2.57 \\
\hline \multicolumn{10}{|l|}{ Education/ research } \\
\hline 016 & Kathmandu Forestry College & $\mathrm{KFC}$ & 4 & 7 & 6.41 & 8 & 4.05 & 7.50 & 5.23 \\
\hline 017 & Kathmandu University & $\mathrm{KU}$ & 5 & 3 & 0.44 & 3 & 1.43 & 3.00 & 0.93 \\
\hline \multicolumn{10}{|c|}{ Business associations } \\
\hline 019 & Federation of Forestry Based Industry and Trade Nepal & FFBITN & 3 & 1 & 0.00 & 0 & 0.00 & 0.50 & 0.00 \\
\hline 020 & $\begin{array}{c}\text { Federation of Nepalese Chambers of Commerce and } \\
\text { Industries }\end{array}$ & FNCCI & 10 & 1 & 0.17 & 2 & 0.11 & 1.50 & 0.14 \\
\hline \multicolumn{10}{|c|}{ International nongovernmental organizations } \\
\hline 033 & Asia Network for Sustainable Agriculture and Bioresources & ANSAB & 15 & 13 & 16.24 & 8 & 5.51 & 10.50 & 10.88 \\
\hline 034 & Center for People and Forests & RECOFTC & 9 & 10 & 89.04 & 15 & 65.52 & 12.50 & 77.28 \\
\hline 035 & World Wide Fund for Nature & WWF & 19 & 13 & 45.28 & 19 & 63.20 & 16.00 & 54.24 \\
\hline 036 & $\begin{array}{c}\text { International Centre for Integrated Mountain } \\
\text { Development }\end{array}$ & ICIMOD & 19 & 17 & 105.84 & 18 & 36.49 & 17.50 & 71.17 \\
\hline 037 & Winrock International & Winrock & 10 & 7 & 1.05 & 9 & 14.11 & 8.00 & 7.58 \\
\hline 040 & CARE Nepal & CARE Nepal & 7 & 7 & 0.99 & 8 & 0.17 & 7.50 & 0.58 \\
\hline \multicolumn{10}{|l|}{ Donor agencies } \\
\hline 045 & World Bank Forest Carbon Trust Fund & WB-FCPF & 15 & 10 & 47.08 & 12 & 23.56 & 11.00 & 35.32 \\
\hline 046 & Swiss Development Corporation & SDC & 8 & 5 & 0.51 & 15 & 14.38 & 10.00 & 7.44 \\
\hline 047 & Department for International Development, UK & DFID & 12 & 9 & 8.42 & 19 & 41.02 & 14.00 & 24.72 \\
\hline 048 & Embassy of Finland & FinEmb & 7 & 6 & 0.73 & 9 & 1.19 & 7.50 & 0.96 \\
\hline 051 & U.S. Agency for International Development & USAID & 7 & 5 & 17.88 & 10 & 17.04 & 7.50 & 17.46 \\
\hline \multirow[t]{2}{*}{052} & Netherlands Development Organization & SNV & 7 & 4 & 0.16 & 11 & 1.52 & 7.50 & 0.84 \\
\hline & & Average: & 14.29 & 9.24 & 29.65 & 11.62 & 22.15 & 10.43 & 25.90 \\
\hline
\end{tabular}

$\dagger$ Average in-degree centrality does not include perceived influence.

Boldface font indicates above-average values.

influential include some of the INGOs and CSOs, donor agencies, educational/research institutions, and, in particular, business associations. There is considerable disparity in the perceived influence of actors within the INGOs and CSOs, and less disparity among donor agencies, whereas all of the educational/research institutions and business associations are seen as having low influence.

\section{Information exchange and collaboration}

Government actors, CSOs, and INGOs dominate the information exchange network, as shown by their higher-than-average indegree/betweenness centrality values and their higher core- periphery ratios (Table 4). The most dominant actor groups are government (REDD Cell, DoF, MoEnv, DFRS, DNPWC, MoLD), INGOs (ICIMOD, WWF, ANSAB, RECOFTC), and CSOs (FECOFUN, NEFIN, FA, NFA, DANAR). Two donor agencies (WB-FCPF and USAID) and one educational/research institution (KFC) are also located in the core, although their importance (in-degree centrality) is lower.

The same three actor groups dominate the collaboration network. Specifically, the most dominant groups (and actors) are INGOs (RECOFTC, WWF, Winrock, ICIMOD), government (REDD Cell, DNPWC, DoF), and CSOs (NEFIN, FECOFUN, NFA). 
Table 3. Actor groups in the REDD+ policy domain in Nepal.

\begin{tabular}{lcc}
\hline \hline National policy domain actor group & Number identified & Number surveyed \\
\hline Government & $15(28 \%)$ & $8(23 \%)$ \\
Education/research & $3(6 \%)$ & $2(6 \%)$ \\
National nongovernmental organizations/civil society organizations & $12(22 \%)$ & $10(29 \%)$ \\
Business associations & $3(6 \%)$ & $2(6 \%)$ \\
International nongovernmental organizations & $11(21 \%)$ & $6(18 \%)$ \\
Multi-lateral/bilateral donors & $9(17 \%)$ & $6(18 \%)$ \\
Total & $53(100 \%)$ & $34(100 \%)$ \\
\hline
\end{tabular}

The most marginalized groups (and actors) include business associations (FFBITN, FNCCI), educational/research institutions (KFC, KU), and donor agencies (all except DFID). Several government actors and CSOs are found in the periphery (five and seven, respectively), while only one INGO plays a marginal role (CARE Nepal).

In both the information exchange and collaboration network relations, the core includes those actors with the most links to each other in information sharing and collaboration on REDD+ policy issues (Fig. 2a,b, round nodes). Government, CSOs, and INGOs have the highest proportion of core actors (Table 4, coreperiphery ratios), underscoring their central role in both relations. Similarly, the most marginalized groups of actors in information exchange and collaboration are business associations, followed by educational/research institutions, donor agencies, and many CSOs, as indicated by their position in the periphery. Despite relatively denser relations among core actors, actors in the periphery (Fig. 2a,b, square nodes) also engage in information exchange and collaboration. However, this exchange is mainly with core actors and not with other peripheral actors.

\section{Information sharing and collaboration among actor groups (centralization and homophily)}

Information exchange and, especially, collaboration on REDD+ issues are relatively centralized, with in-degree centralization values of $68 \%$ and $51 \%$, respectively (Appendix 2), and are thus influenced by the most dominant actor (REDD Cell) and by other powerful intermediaries in the core, with relatively little direct interaction among more peripheral actors (Fig. 2a,b). This indicates that REDD Cell has substantial control over information flows and moderate influence over collaborations. Despite this central position in information exchange and collaboration, the degree to which REDD Cell and other dominant actors serve as exclusive brokers of information and collaboration between other actors is relatively low, with betweenness centralization values of $21 \%$ and $13 \%$, respectively.

The density of interactions among and within actor groups for both information exchange and collaboration reveals high levels of interaction between INGOs, CSOs, and government (Table 5). Intergroup information exchange is highest from INGOs to government (0.48) and from INGOs to CSOs (0.48), with much fewer ties from government to CSO (0.28). Intergroup collaboration is highest for INGOs to CSOs $(0.58)$ and INGOs to government (0.52). Donors and educational/research institutions also interact frequently with the aforementioned actor groups, but interactions involving the private sector and academic institutions are much more limited. INGOs exhibit the highest level of internal interaction (homophily) for information exchange and collaboration ( 0.70 and 0.70 , respectively), followed by government ( 0.50 and 0.63 ) and donor agencies ( 0.40 and 0.53 ). However, these homophily values are only statistically significant $(P<0.05)$ for INGOs and government.

\section{Overall importance of actor groups and actors in the REDD+ policy arena across network variables and measures}

Comparing the groups on the given measures with the average for all actors and taking the average proportion for all measures and networks indicates the overall importance (i.e., power) of each actor group in the REDD+ policy arena (Table 6). In general, INGOs (average proportion $=1.64$ ) and government $(1.40)$ have the most power in REDD+ policy making across all network relations and measures, followed by CSOs, with an average combined power of just above average (1.02). Donor agencies are somewhat below average (0.86), while educational/research institutions (0.47), and especially business associations (0.03), are consistently below average. Government actors have the highest average perceived influence, followed by CSOs. Government actors dominate in information exchange in terms of centrality (in-degree and betweenness), whereas INGOs exhibit the highest homophily and percentage of actors in the core. With respect to collaboration ties, government, CSOs, donors, and INGOs are similar in terms of their in-degree centrality, but INGOs are significantly higher in both homophily and their core-periphery ratio.

The analysis indicates that REDD+ policy making in Nepal clearly does not represent a purely state-centric model, given that some INGOs and CSOs wield considerable power and that donor organizations also play a relatively important role in key network relations. Nor does it resemble an iron triangle (an exclusive threeway relationship involving government bureaucracy, the legislature, and powerful interest groups) or a polycentric governance model, with diverse multi-stakeholder participation and influence. Instead of broad-based participation or highly dispersed and deliberative decision making, I find evidence that REDD+ policy processes in Nepal are dominated by a "development triangle", that is, a strong tripartite alliance of dense interactions among a select set of key government organizations, influential INGOs, and powerful CSOs. Moderate involvement by donor agencies reinforces the influence of INGOs. Important domestic stakeholders from the private sector, academia, and civil society are only marginally involved or are excluded altogether.

I now discuss the roles of powerful individual actors in the development triangle and their collective influence on policy 
Table 4. Relative prominence of REDD+ actor groups in Nepal in perceived influence, information exchange, and collaboration.

\begin{tabular}{|c|c|c|c|c|c|c|c|c|c|}
\hline \multirow[b]{2}{*}{$\begin{array}{l}\text { Organization } \\
\text { type (actor } \\
\text { group) }\end{array}$} & \multirow{2}{*}{$\begin{array}{c}\text { Perceived } \\
\text { influence } \\
\text { Average in- } \\
\text { degree } \\
\text { centrality }\end{array}$} & \multicolumn{4}{|c|}{ Information exchange } & \multicolumn{4}{|c|}{ Collaboration } \\
\hline & & $\begin{array}{l}\text { Average in- } \\
\text { degree } \\
\text { centrality } \\
\end{array}$ & $\begin{array}{c}\text { Average } \\
\text { betweenness } \\
\text { centrality } \\
\end{array}$ & $\begin{array}{l}\text { Core } \dagger(\% \text { in } \\
\text { core })\end{array}$ & Periphery† & $\begin{array}{l}\text { Average in- } \\
\text { degree } \\
\text { centrality } \\
\end{array}$ & $\begin{array}{c}\text { Average } \\
\text { betweenness } \\
\text { centrality } \\
\end{array}$ & $\begin{array}{l}\text { Core } \dagger(\% \text { in } \\
\text { core })\end{array}$ & Periphery† \\
\hline Government & 21.88 & 11.75 & 58.64 & $4(\mathbf{5 0})$ & 4 & 12.50 & 30.98 & $3(38)$ & 5 \\
\hline $\begin{array}{l}\text { Civil society } \\
\text { organizations }\end{array}$ & 15.40 & 10.20 & 19.86 & $5(\mathbf{5 0})$ & 5 & 12.90 & 21.59 & $3(30)$ & 7 \\
\hline $\begin{array}{l}\text { Education/ } \\
\text { research }\end{array}$ & 4.50 & 5.00 & 3.42 & $1(\mathbf{5 0})$ & 1 & 5.50 & 2.74 & $0(0)$ & 2 \\
\hline $\begin{array}{l}\text { Business } \\
\text { associations }\end{array}$ & 6.50 & 1.00 & 0.08 & $0(0)$ & 2 & 1.00 & 0.06 & $0(0)$ & 2 \\
\hline $\begin{array}{l}\text { International } \\
\text { nongovern- } \\
\text { mental } \\
\text { organizations }\end{array}$ & 13.17 & 11.17 & 43.07 & $4(67)$ & 2 & 12.83 & 30.83 & $5(\mathbf{8 3})$ & 1 \\
\hline $\begin{array}{l}\text { Donor } \\
\text { agencies }\end{array}$ & 9.33 & 6.50 & 12.46 & $2(33)$ & 4 & 12.67 & 16.45 & $1(17)$ & 5 \\
\hline $\begin{array}{l}\text { Average/ } \\
\text { total } / \% \text { (all } \\
\text { actors) }\end{array}$ & 14.29 & 9.24 & 29.65 & $16(47)$ & 18 & 11.62 & 22.15 & $12(35)$ & 22 \\
\hline
\end{tabular}

$\dagger$ Total number of actors in the core or periphery.

$\$$ Boldface font indicates that the group average is higher than the average for all actors.

processes for forestry and REDD+ in Nepal. Dominant government actors include REDD Cell, DoF, MoEnv, DFRS, DNPWC, and MoLD. All except for MoEnv and MoLD fall under the Ministry of Forests and Soil Conservation (MoFSC) and have direct responsibility for forestry research and policy formulation. MoEnv has a broader mandate than MoFSC and serves as the government's focal point for the United Nations Framework Convention on Climate Change, albeit not for REDD+. DoF and DFRS exhibit above-average reputational power, information exchange, and collaboration (in-degree centrality), likely due to their key involvement in policy-making and piloting activities. DNPWC, while lower in terms of perceived influence and participation in information exchange and collaboration (in-degree centrality), serves as an important broker of both information and collaboration among other actors (with high betweenness centrality). This could be explained by DNPWC's interaction with other, more influential actors and the fact that its director is the former head of REDD Cell. Other government actors, namely MoAgr, DSCWM, and MoLD, have low reputational power and little involvement in information sharing and collaboration (i.e., peripheral status and low indegree centrality), but are nonetheless important partners for implementing REDD+ because of their potential to influence the major drivers of deforestation and forest degradation. Furthermore, MoLD plays an important brokering role in information exchange. Conversely, MoEnv has high reputational power and significant involvement in information exchange, but low capacity as a broker, especially for facilitating collaboration.

REDD Cell is by far the most dominant actor in the policy network. As the national coordinating entity for REDD+ and the primary recipient and distributor of donor support, REDD Cell provides information to and collaborates with a large number of actors, but has more power to manipulate the exchange of information than to affect collaboration among more peripheral actors. The high level of centralization for information exchange and the moderate level for collaboration indicate that communication and partnerships are significantly mediated by REDD Cell and other central actors in the development triangle (e.g., FECOFUN, DoF, FA, NEFIN, ICIMOD, WWF), with less horizontal interaction and coordination among other actors. This potential to distort or control information has implications for the extent of awareness, involvement, and influence of more peripheral actors, creating a potential imbalance or constraint for deliberative policy making. If some actors and groups are not sharing information or collaborating with each other regularly, their capacity to understand and influence policy making could be restricted. However, this also depends on the specific nature and depth of interactions or relations involving more peripheral actors.

The most important INGOs are ICIMOD, WWF, ANSAB, and RECOFTC, all of which have played coordinating and consultative roles in REDD+ pilot projects and policy discussions. ICIMOD and WWF were technical leads on Nepal's first two REDD+ pilot projects, and ANSAB has been closely involved in developing both technical guidelines for carbon accounting and a sub-national mechanism for distributing REDD+ payments. RECOFTC has been closely involved in outreach and awareness-raising activities.

Powerful CSOs include FECOFUN, NEFIN, FA, and NFA. Most of the policy debates and pilot projects on REDD+ have targeted community forest user groups and, to a lesser extent, indigenous communities, while sidelining other important stakeholders and forest management regimes such as private forests, collaborative forest management, national forests, and protected areas. My results suggest that this is due to the prominence of FECOFUN and NEFIN in deliberations and 
Table 5. Comparison of group-wise density of interaction among and within actor groups for information exchange and collaboration networks in Nepal's REDD+ policy arena. Scores indicate the density of interactions (as a proportion of all possible ties) among and within actor groups; a score of 0.48 means that $48 \%$ of all possible ties are realized. ANOVA test for goodness of fit is significant $(P$ $<0.05$ ) for government and international nongovernmental organizations.

\begin{tabular}{|c|c|c|c|c|c|c|c|c|c|c|c|c|c|c|}
\hline & \multicolumn{2}{|c|}{ Govt } & \multicolumn{2}{|c|}{ Educ./res.t } & \multicolumn{2}{|c|}{$\mathrm{CSOs} \S$} & \multicolumn{2}{|c|}{ Bus. assoc.| } & \multicolumn{2}{|c|}{ INGOs $\Phi$} & \multicolumn{2}{|c|}{ Donors } & \multicolumn{2}{|c|}{ Average (row-wise) } \\
\hline & Info.\# & Coll. $+\dagger$ & Info. & Coll. & Info. & Coll. & Info. & Coll. & Info. & Coll. & Info. & Coll. & Info. & Coll. \\
\hline Gov & 0.50 & 0.63 & 0.19 & 0.19 & 0.28 & 0.35 & 0.13 & 0.06 & 0.27 & 0.40 & 0.17 & 0.50 & 0.25 & 0.35 \\
\hline Educ./res. & 0.38 & 0.38 & 0.00 & 0.50 & 0.30 & 0.25 & 0.00 & 0.00 & 0.25 & 0.25 & 0.08 & 0.50 & 0.17 & 0.31 \\
\hline CSOs & 0.30 & 0.31 & 0.05 & 0.05 & 0.38 & 0.41 & 0.00 & 0.00 & 0.28 & 0.37 & 0.10 & 0.23 & 0.19 & 0.23 \\
\hline Bus. assoc. & 0.06 & 0.00 & 0.00 & 0.00 & 0.10 & 0.10 & 0.00 & 0.00 & 0.00 & 0.00 & 0.00 & 0.00 & 0.03 & 0.02 \\
\hline INGOs & 0.48 & 0.52 & 0.33 & 0.25 & 0.48 & 0.58 & 0.00 & 0.08 & 0.70 & 0.70 & 0.33 & 0.44 & 0.39 & 0.43 \\
\hline Donors & 0.25 & 0.19 & 0.17 & 0.25 & 0.15 & 0.37 & 0.00 & 0.00 & 0.36 & 0.33 & 0.40 & 0.53 & 0.22 & 0.28 \\
\hline
\end{tabular}

†overnment. \$Education/research. §Civil society organizations. |Business associations. "International nongovernmental organizations. \#Information exchange networks. ††Collaboration networks.

piloting activities. Although there is widespread representation and participation by these two organizations and their constituencies at both the national and grassroots levels, a number of CSOs representing other important constituencies have had only marginal involvement and trivial influence in REDD+ policy making. These constituencies include women, Dalits (members of the "untouchable" caste), professionals working to support community forestry, and participants in other community-based regimes such as collaborative forest management and leasehold forestry. Without substantial buy-in and participation from these additional constituencies, it is doubtful that REDD+ could be implemented effectively, efficiently, or equitably on a national level. Furthermore, information exchange and collaboration are relatively low among CSOs, compared with INGOs, government, and donors. This points to a lack of cooperation and communication among CSOs, which could hinder the potential for the key CSOs (e.g., FECOFUN, NEFIN, FA) to represent effectively the interests of more marginalized civil society actors.

\section{DISCUSSION}

With its uneven, multi-sector institutional landscape characterized by strong influence and ties among government organizations, powerful INGOs, and influential CSOs (i.e., a development triangle) and scant involvement by the private sector, forest governance in Nepal resembles neither a purely state-centric nor a market-oriented model. Yet with (perceived) influence, information sharing, and collaboration concentrated among relatively few actors and sectors, and civil society involvement limited to a few powerful CSOs, it does not reflect broad-based polycentric (or network) governance either. Rather, the pendulum of forest governance seems to be wavering between state-centric and polycentric, with limited influence from the market. With a government-dominated policy process, an INGO/donor-driven agenda, narrow and token involvement from civil society, and the exclusion of many important constituencies and stakeholders, the practice of REDD+ policy making in Nepal threatens to push the pendulum back toward a more techno-bureaucratic, centralized mode of forest governance. This regressive force and its consequences can be attributed to several factors.

It is widely held that the effectiveness of governance of socialecological systems in general, and of far-reaching policy mechanisms such as REDD+ in particular, depends on broad participation and deliberation among a wide range of actors from multiple sectors (Stringer et al. 2006, Pokharel and Baral 2009). In Nepal, however, the development triangle hinders participation by important actors from the private, academic, and civil society sectors, which are either marginalized or completely excluded from the process. Rather than an inclusive network of horizontal relations, there is considerable disparity in the influence, importance, and connectedness of actors across key relations representing vital dimensions of policy making, with sparse interaction among and within some actor groups. This unevenness does not reflect the normative ideal of polycentric or network governance. It undermines the capacity for many actors to participate in and benefit from REDD+ and hinders the development and implementation of effective policies.

One key finding is that external actors (INGOs and donors) have more impact on REDD+ policy making than is perceived and are driving the process to a large extent. Although government and CSOs have more reputational power (perceived influence), INGOs have greater importance across nearly all network measures for information exchange and collaboration (Table 6). With the power of INGOs augmented by the collaboration and resources of donors, the strong influence of external actors is not surprising, especially considering that international organizations have played a major role in Nepal's forestry sector for decades (Ojha 2011). In fact, it was largely due to technical and financial support from multi-lateral and bilateral donors that community forestry first took root in the 1970s and 1980s (Gilmour and Fisher 1991). However, heavy INGO/donor influence in policy making could have detrimental effects on the long-term financing and implementation of REDD+ in Nepal. The current aid-driven approach means that alternative financing channels are not being explored. Nepal has had no direct experience with either regulatory or private-sector (voluntary) forest-carbon trading, which could adversely affect its flexibility and competitiveness in participating in global carbon markets. Moreover, some researchers claim that the strict guidelines imposed by WB-FCPF for the R-PP process reinforce a techno-bureaucratic approach and limit the nature and degree of participation in this process (Bushley 2010).

Along with external actors, it is clear that government drives REDD+ policy making in Nepal. Powerful actors within the 
Table 6. Group averages for network measures as a proportion of the average for all actors for each network variable. Results indicate the relative overall importance (i.e., power) of each actor group in the REDD+ policy arena.

\begin{tabular}{|c|c|c|c|c|c|c|c|c|c|c|}
\hline \multirow[b]{2}{*}{ Actor group } & \multicolumn{3}{|c|}{ In-degree centrality } & \multicolumn{2}{|c|}{$\begin{array}{l}\text { Betweenness } \\
\text { centrality }\end{array}$} & \multicolumn{2}{|c|}{ Core-periphery ratio } & \multicolumn{2}{|c|}{ Homophily } & \multirow[b]{2}{*}{$\begin{array}{l}\text { Average (excluding } \\
\text { perceived influence) }\end{array}$} \\
\hline & $\begin{array}{l}\text { Perceived } \\
\text { influence }\end{array}$ & Info.t & Coll. $\S$ & Info. & Coll. & Info. & Coll. & Info. & Coll. & \\
\hline Government & 1.46 & 1.27 & 1.06 & 1.98 & 1.40 & 1.06 & 1.09 & 1.52 & 1.85 & 1.40 \\
\hline Civil society organizations & 1.08 & 1.10 & 1.11 & 0.67 & 0.97 & 1.06 & 0.86 & 1.15 & 1.21 & 1.02 \\
\hline Education/research & 0.34 & 0.54 & 0.47 & 0.12 & 0.12 & 1.06 & 0.00 & 0.00 & 1.47 & 0.47 \\
\hline Business associations & 0.45 & 0.11 & 0.09 & 0.00 & 0.00 & 0.00 & 0.00 & 0.00 & 0.00 & 0.03 \\
\hline $\begin{array}{l}\text { International } \\
\text { nongovernmental } \\
\text { organzations }\end{array}$ & 0.92 & 1.21 & 1.10 & 1.45 & 1.39 & 1.43 & 2.37 & 2.12 & 2.06 & 1.64 \\
\hline Donor agencies & 0.65 & 0.70 & 1.09 & 0.42 & 0.74 & 0.70 & 0.49 & 1.21 & 1.56 & 0.86 \\
\hline
\end{tabular}

$\dagger$ ANOVA test for goodness of fit is significant $(P<0.05)$ for government and international nongovernmental organizations.

Information exchange network.

$\S$ Collaboration network.

MoFSC (especially REDD Cell, but also DoF and DFRS) and the MoEnv have strong influence over information sharing and collaboration. However, the failure to involve other influential government stakeholders effectively, such as the Ministries of Agriculture, Land Reform, and Energy, presents a challenge for addressing Nepal's diverse drivers of deforestation and forest degradation.

Some CSOs are also closely involved in REDD+ dialogs and activities but have little direct influence in policy making. They play an important role in coordinating projects, especially at the grassroots level, but exhibit less communication and collaboration with other national actors (lower homophily and density of interactions) than their counterpart government, INGO, and donor organizations. Although the significant involvement by local communities and indigenous people in REDD+ policy making and pilot projects in Nepal could suggest polycentricity (e.g., Ostrom 2010), there are significant gaps in participation, particularly in the deliberative (horizontal) aspect of polycentric governance, by sectors and actors crucial to the success of REDD+. CSOs also have weak representation in official decision-making forums, holding just 2 of 12 positions (NEFIN and FECOFUN) in the REDD Working Group, the official body for REDD+ policy development (the remaining 10 positions include eight representatives from government, one donor representative, and one independent expert; Bushley and Khatri 2011). Consequently, their impact on policy making is limited. So why are CSOs perceived as playing a more significant role than INGOs? It may be partly due to their visibility and voice in projects and advocacy forums, although this does not necessarily translate into political influence. In contrast, INGOs and donors exercise power behind the scenes, through direct consultations and advice given to REDD Cell.

The lack of private sector participation in REDD policy making in Nepal is another important finding, given that REDD+ was conceived as a market-based mechanism. Domestic companies can play two main roles in REDD+: investing in carbon offsets; and producing commercial products and market-based solutions that help reduce deforestation and forest degradation. Although the first is not essential because external funding sources are anticipated, the second is crucial for the effective realization of REDD+. Thus, the paucity of private sector involvement in relevant policy forums and activities could affect the success of REDD+ in Nepal in the longer term. As in other countries, REDD+ policy development in Nepal is driven by external (INGO and donor) agendas, hampering investments by private sector actors.

Effectively reducing emissions from deforestation and forest degradation requires governing a wide range of land-cover types, commercial and livelihood activities, and ecosystem services (Angelsen 2009), and involving all management regimes that could help to realize reductions. So far, other modes of forest management, besides community forestry, have been excluded from the REDD+ process in Nepal, including private and government-managed forests, as well as other participatory forestry schemes such as collaborative forest management and leasehold forestry. Furthermore, there is little evidence of efforts to engage stakeholders that influence decisions about land and resource tenure and use, such as private companies, powerful government entities outside the forestry sector (such as the Ministries of Agriculture, Land Reform, and Energy), diverse local landholders, and commercial interests.

There are a host of institutional challenges inherent in REDD+ that must be resolved to guarantee its effective, efficient, and equitable implementation (Angelsen et al. 2012). In Nepal, the externally driven, state-centered REDD+ agenda has privileged certain aspects of policy making over others. Whereas policy making and piloting activities have emphasized systems for monitoring, reporting, and verification of carbon stocks and benefit sharing at the grassroots level, national-level monitoring and financial architecture is less apparent, and major social, institutional, and ecological concerns have been largely overlooked. For instance, such critical issues as defining and securing carbon tenure; promoting broad-based benefit-sharing systems; ensuring protection of biodiversity; increasing awareness and obtaining free, prior and informed consent; and creating a role for private (voluntary market) projects and investments have hardly been addressed. External actors are also complicit in the failure to address these issues. CSOs have attempted to convene 
dialogs on these and other important aspects of REDD+ governance, but these have had little direct impact on policy making.

This analysis is not without limitations. For instance, a more indepth, accurate assessment of inclusiveness and deliberation in Nepal's REDD+ policy process would examine participation in specific decision-making forums and events and explore the quality of interactions among actors. Nevertheless, my findings point to an imbalance in policy making. Furthermore, although this research did not explicitly address decentralization, it is clear that REDD+ policy making in Nepal, with its exclusive and centralized nature and its failure to involve many important stakeholders, is doing little to further decentralized, communitybased forest governance. Although there is no compelling evidence to date in Nepal, there is concern that the emphasis on more technical aspects of governance, the disproportionate influence of state and external actors, along with institutional uncertainties and incentives for the state to capture benefits from carbon trading, could lead to a recentralization of forest governance (e.g., Phelps et al. 2010).

\section{CONCLUSION}

Employing social network analysis, I analyzed the influence and power of 34 policy actors in three key aspects of REDD+ policy making, namely reputational power (perceived influence), information exchange, and collaboration, through an assessment of inclusiveness and deliberation based on the level of dominance, marginalization, and interaction among actors. The results suggest that the exchange of information and collaboration related to REDD+ are dominated by key government organizations and by a few INGOs and CSOs coordinating pilot projects. As a result, related policies and discourses have been largely shaped by interactions among a limited set of actors, and the advent of REDD+ has done little to engage the private sector or to loosen the grip of the state on the policy process. By failing to engage important stakeholders at national and sub-national levels, REDD+ policy making has enabled a powerful coalition of select government, donor/INGO, and civil society actors to dominate the policy process while marginalizing the voices and roles of other crucial stakeholders from the private, academic, and civil society sectors, as well as a few key government entities. As a result, the process lacks valuable input and support from timber and forest product industries, scholars of forest governance, government agencies outside of the forestry sector, and CSOs representing Dalits, women, private landowners, and other local forest users. However, involvement of these stakeholders is critical to realizing effective, efficient, and equitable forest governance and conservation and to the successful implementation of policies such as REDD+. As Thompson et al. (2011:100) observe, "Even as it takes shape, REDD+ is already functioning as a form of governance, a particular framing of the problem of climate change and its solutions that validates and legitimizes specific tools, actors and solutions while marginalizing others." Consequently, there is a risk that, far from being a neutral policy mechanism, REDD+ may promote the recentralization of forest governance by allowing a "development triangle" coalition composed of a few powerful government, INGO, and civil society actors to dominate the policy process while simultaneously suppressing the roles and voices of many important stakeholders.
The ecological consequences of such a shift in forest governance are uncertain. However, if we accept that community forestry has contributed to the regeneration of forests in many parts of Nepal (Pokharel et al. 2007), and that collaboration, information sharing, and deliberative governance are essential for the sustainable management of forests (Andersson 2006, Tucker 2010), then the degradation of collaborative, people-centered, deliberative, multi-use, decentralized approaches to forestry in favor of a more top-down, techno-bureaucratic model controlled by a limited number of powerful actors will likely have an adverse effect on forest ecosystems and the livelihoods of the communities that rely on them. My research suggests that the current policymaking process in Nepal is thwarting the realization of effective, efficient, and equitable outcomes for REDD+ and is jeopardizing the impressive social and ecological gains of community forestry.

\section{Responses to this article can be read online at: http://www.ecologyandsociety.org/issues/responses. php/6853}

\section{Acknowledgments:}

I thank the Center for International Forestry Research (CIFOR) for financial, technical, and editorial support. In particular, I am extremely grateful to Maria Brockhaus, Monica Di Gregorio, Rachel Carmenta, Christina Wairata, Efrian Muharrom, Sofi Mardiah, and the CIFOR communications team for their tireless support with research and editing and their constructive feedback. I am also deeply indebted and thankful to my colleagues at ForestAction Nepal, especially to Dil Bahadur Khatri and Naya Sharma Paudel, for their logistical and moral support during administration and analysis of the survey; and to Dipak Bishwokarma, Rahul Karky, and Niru Gurung for their invaluable assistance with collecting and analyzing the survey data and transcribing interviews. Last, but certainly not least, I am very grateful to those who participated in the policy network survey for sharing their valuable time, insights, and perspectives. This research is part of the policy component (Brockhaus and Di Gregorio 2012) of a wider Global Comparative Study on REDD+ (http://www. forestsclimatechange.org/global-comparative-study-on-redd.html), led by CIFOR. Funding was provided by the Norwegian Agency for Development Cooperation, the Australian Agency for International Development, the UK Department for International Development, and the European Commission. The methods applied in this study build partially on research undertaken by the Comparing Climate Change Policy Networks program (http://compon.org), funded by the National Science Foundation.

\section{LITERATURE CITED}

Agrawal, A., A. Chhatre, and R. Hardin. 2008. Changing governance of the world's forests. Science 320:1460-1462. http:// dx.doi.org/10.1126/science.1155369

Agrawal, A., and E. Ostrom. 2008. Decentralization and community-based forestry: learning from experience. Pages 44-67 in E. L. Webb and G. P. Shivakoti, editors. Decentralization, forests and rural communities: policy outcomes in South and Southeast Asia. Sage, New Delhi, India. 
Andersson, K. 2006. Understanding decentralized forest governance: an application of the institutional analysis and development framework. Sustainability: Science, Practice, and Policy 2(1):25-35. [online] URL: http://sspp.proquest.com/ archives/vol2iss1/0507-010.andersson.html.

Andersson, K., T. Evans, C. Gibson, and G. Wright. 2012. Decentralization and deforestation: the moderating role of polycentric governance. Paper presented at the 16th Annual Conference of the International Society for New Institutional Economics, June 14-16, Los Angeles, California, USA. [online] URL: http://papers.isnie.org/paper/907.html.

Andersson, K. P., and E. Ostrom. 2008. Analyzing decentralized resource regimes from a polycentric perspective. Policy Sciences 41(1):71-93. http://dx.doi.org/10.1007/s11077-007-9055-6

Angelsen, A., editor. 2008. Moving ahead with REDD: issues, options and implications. Center for International Forestry Research, Bogor, Indonesia. [online] URL: http://www.cifor.org/ publications/pdf files/books/bangelsen0801.pdf.

Angelsen, A. 2009. Introduction. Pages 1-12 in A. Angelsen, M. Brockhaus, M. Kanninen, E. Sills, W. D. Sunderlin, and S. WertzKanounnikoff, editors. Realising REDD+: national strategy and policy options. Center for International Forestry Research, Bogor, Indonesia. [online] URL: http://www.cifor.org/publications/ pdf_files/books/bangelsen0902.pdf.

Angelsen, A., M. Brockhaus, W. D. Sunderlin, and L. V. Verchot, editors. 2012. Analysing REDD+: challenges and choices. Center for International Forestry Research, Bogor, Indonesia. [online] URL: http://www.cifor.org/publications/pdf files/Books/BAngelsen1201. pdf.

Bodin, Ö., and C. Prell, editors. 2011. Social networks and natural resource management: uncovering the social fabric of environmental governance. Cambridge University Press, Cambridge, UK. http:// dx.doi.org/10.1017/CBO9780511894985

Borgatti, S. P., M. G. Everett, and L. C. Freeman. 2002. UCINET for Windows: software for social network analysis. Analytic Technologies, Harvard, Massachusetts, USA. [online] URL: https://sites.google.com/site/ucinetsoftware/home.

Britt, C. 2010. Changing the boundaries of forest politics: community forestry, social mobilization, and federation-building in Nepal. Lambert Academic Publishing, Saarbrücken, Germany.

Bushley, B. R. 2010. Seeing the communities for the carbon: governance challenges of reducing emissions from deforestation and forest degradation in Nepal. Reconsidering Development 1(1). [online] URL: http://reconsideringdevelopment.org/issues/i/ seeing-the-communities-for-the-carbon/.

Bushley, B. R., and D. B. Khatri. 2011. REDD+: reversing, reinforcing or reconfiguring decentralized forest governance in Nepal? Discussion paper series 11.3. ForestAction Nepal, Kathmandu, Nepal. [online] URL: http://www.forestrynepal.org/ publications/reports/5450.

Carlsson, L. G., and A. C. Sandström. 2008. Network governance of the commons. International Journal of the Commons 2 (1):33-54. [online] URL: http://www.thecommonsjournal.org/ index.php/ijc/article/view/20.
Cashore, B. 2002. Legitimacy and the privatization of environmental governance: how non-state market-driven (NSMD) governance systems gain rule-making authority. Governance 15(4):503-529. http://dx.doi.org/10.1111/1468-0491.00199

Crona, B., and K. Hubacek, editors. 2010. Social network analysis in natural resource governance. Ecology and Society 15(4). [online] URL: www.ecologyandsociety.org/issues/view.php?sf=48.

Dahal, G. R. 2003. Devolution in the context of poor governance: some learning from community forestry in Nepal. Journal of Forest and Livelihood 2(2):17-22.

Davies, J. S. 2012. Network governance theory: a Gramscian critique. Environment and Planning A 44(11):2687-2704. http://dx. doi.org/10.1068/a4585

Dedeurwaerdere, T. 2005. The contribution of network governance to sustainable development. Les séminaires de l'Iddri, number 13. Institut du développement durable et des relations internationales, Paris, France. [online] URL: www.iddri.org/ Evenements/Seminaires-reguliers/s13 dedeurwaerdere.pdf.

Dedeurwaerdere, T. 2007. Network institutions and environmental governance: democratic accountability reconsidered. Pages 251-262 in P. Le Prestre and L. Tubiana, editors. Toward collective action on international environmental governance: proceedings of the Paris workshop, March 15-16, 2004. IDDRI, Paris, France, and IHQEDS, Quebec, Canada. [online] URL: http://www.iddri. org/Publications/Toward-Collective-Action-On-InternationalEnvironmental-Governance.

Department of Forests. 2011. Status of Community Forestry: Sept. 01, 2011. Community Forestry Division, Ministry of Forests and Soil Conservation, Government of Nepal, Kathmandu, Nepal. [online] URL: http://dof.gov.np/dof_community_orest_division/ community forestry dof and http://dof.gov.np/image/data/ Community Forestry/cfdatabase.pdf.

Devkota, R. R. 2010. Interests and power as drivers of community forestry: a case study of Nepal. Göttingen University, Göttingen, Germany.

Dryzek, J. S. 2010. Foundations and frontiers of deliberative governance. Oxford University Press, Oxford, UK. http://dx.doi. org/10.1093/acprof:oso/9780199562947.001.0001

Gibson, C. C., M. A. McKean, and E. Ostrom, editors. 2000. People and forests: communities, institutions, and governance. MIT Press, Cambridge, Massachusetts, USA.

Gilmour, D. A., and R. J. Fisher. 1991. Villagers, forests, and foresters: the philosophy, process, and practice of community forestry in Nepal. Sahayogi Press, Kathmandu, Nepal.

Guthman, J. 1997. Representing crisis: the theory of Himalayan environmental degradation and the project of development in post-Rana Nepal. Development and Change 28(1):45-69. http:// dx.doi.org/10.1111/1467-7660.00034

Hanneman, R. A., and M. Riddle. 2005. Introduction to social network methods. University of California, Riverside, California, USA. [online] URL: http://faculty.ucr.edu/ hanneman/.

Hawe, P., C. Webster, and A. Shiell. 2004. A glossary of terms for navigating the field of social network analysis. Journal of 
Epidemiology and Community Health 58(12):971-975. http://dx. doi.org/10.1136/jech.2003.014530

Iversen, V., B. Chhetry, P. Francis, M. Gurung, G. Kafle, A. Pain, and J. Seeley. 2006. High value forests, hidden economies and elite capture: evidence from forest user groups in Nepal's Terai. Ecological Economics 58(1):93-107. http://dx.doi.org/10.1016/j. ecolecon.2005.05.021

Kanel, K. R. 2008. So far so good: next steps in community forestry. Pages 371-390 in R. Ghate, N. Jodha, and P. Mukhopadhyay, editors. Promise, trust and evolution: managing the commons of South Asia. International Centre for Integrated Mountain Development, Kathmandu, Nepal; IFRI, Indiana University, Bloomington, Indiana, USA; and Goa University, Goa, India.

Kanel, K. R., and G. R. Dahal. 2008. Community forestry policy and its economic implications: an experience from Nepal. International Journal of Social Forestry 1(1):50-60. [online] URL: http://www.ijsf.org/dat/art/vol01/ijsf_vol1_no1_03_kanel_nepal.pdf.

Kenis, P., and V. Schneider. 1991. Policy networks and policy analysis: scrutinizing a new analytical toolbox. Pages 25-59 in B. Marin and R. Mayntz, editors. Policynetworks: empirical evidence and theoretical considerations. Westview Press, Boulder, Colorado, USA.

Lane, M. B. 2003. Decentralization or privatization of environmental governance? Forest conflict and bioregional assessment in Australia. Journal of Rural Studies 19(3):283-294. http://dx.doi.org/10.1016/S0743-0167(02)00084-0

Larson, A. M., and F. Soto. 2008. Decentralization of natural resource governance regimes. Annual Review of Environment and Resources 33:213-239. http://dx.doi.org/10.1146/annurev. environ.33.020607.095522

Nagendra, H. 2007. Drivers of reforestation in human-dominated forests. Proceedings of the National Academy of Sciences 104 (39):15218-15223. http://dx.doi.org/10.1073/pnas.0702319104

Ojha, H. R. 2008. Reframing governance: understanding deliberative politics in Nepal's Terai forestry. Adroit, New Delhi, India.

Ojha, H. R. 2011. Aid dilemma: has foreign aid contributed to community forestry development in Nepal? AAMN Research and Policy Brief 6. Alliance for Aid Monitor Nepal, Kathmandu, Nepal. [online] URL: http://www.aidmonitor.org.np/publication/12. pdf.

Ostrom, E. 2009. Beyond markets and states: polycentric governance of complex economic systems. Nobel Prize lecture. Nobel Media, Stockholm, Sweden. [online] URL: www. nobelprize.org/nobel_prizes/economics/laureates/2009/ostrom_lecture. pdf.

Ostrom, E. 2010. Polycentric systems for coping with collective action and global environmental change. Global Environmental Change 20(4):550-557. http://dx.doi.org/10.1016/j.gloenvcha.2010.07.004

Pandit, R., and E. Bevilacqua. 2011. Forest users and environmental impacts of community forestry in the hills of Nepal. Forest Policy and Economics 13(5):345-352. http://dx.doi. org/10.1016/j.forpol.2011.03.009
Paudel, N. S., D. B. Khatri, D. R. Khanal, and R. Karki. 2013. The context of REDD+ in Nepal: drivers, agents and institutions. Occasional Paper 81. CIFOR, Bogor, Indonesia. [online] URL: http://www.cifor.org/publications/pdf files/OccPapers/OP-81.pdf.

Perkins, E., and J. Court. 2005. Networks and policy processes in international development: a literature review. Working Paper 252. Overseas Development Institute, London, UK. [online] URL: http://www.odi.org/sites/odi.org.uk/files/odi-assets/publications-opinionfiles/160.pdf.

Phelps, J., E. L. Webb, and A. Agrawal. 2010. Does REDD+ threaten to recentralize forest governance? Science 326:312-313. http://dx.doi.org/10.1126/science.1187774

Pokharel, B., and J. Baral. 2009. From green to REDD, from aid to trade: translating the forest carbon project into practice. Journal of Forest and Livelihood 8(1):37-40.

Pokharel, B. K., P. Branney, M. Nurse, and Y. B. Malla. 2007. Community forestry: conserving forests, sustaining livelihoods and strengthening democracy. Journal of Forest and Livelihood 6 (2):8-19.

Pokharel, B. K., and S. Byrne. 2009. Climate change mitigation and adaptation strategies in Nepal's forest sector: How can rural communities benefit? Discussion Paper 7. Nepal Swiss Community Forestry Project, Kathmandu, Nepal.

Ribot, J. C., A. Agrawal, and A. M. Larson. 2006. Recentralizing while decentralizing: how national governments reappropriate forest resources. World Development 34(11):1864-1886. http://dx. doi.org/10.1016/j.worlddev.2005.11.020

Scott, J. 2004. Social network analysis: a handbook. Second edition. Sage, London, UK.

Springate-Baginski, O., and P. Blaikie, editors. 2007. Forests, people and power: the political ecology of reform in South Asia. Earthscan, London, UK.

Springate-Baginski, O., and E. Wollenberg, editors. 2010. REDD, forest governance and rural livelihoods: the emerging agenda. Center for International Forestry Research, Bogor, Indonesia. [online] URL: http://www.cifor.org/publications/pdf files/Books/ BWollenberg0101.pdf.

Stringer, L. C., A. J. Dougill, E. Fraser, K. Hubacek, C. Prell, and M. S. Reed. 2006. Unpacking "participation" in the adaptive management of social-ecological systems: a critical review. Ecology and Society 11(2): 39. [online] URL: www. ecologyandsociety.org/vol11/iss2/art39/.

Sunam, R. K., N. S. Paudel, and G. Paudel. 2013. Community forestry and the threat of recentralization in Nepal: contesting the bureaucratic hegemony in policy process. Society and Natural Resources 26(12):1407-1421. http://dx.doi.org/10.1080/0894192$\underline{0.2013 .799725}$

Thompson, M. C., M. Baruah, and E. R. Carr. 2011. Seeing REDD+ as a project of environmental governance. Environmental Science and Policy 14(2):100-110. http://dx.doi. org/10.1016/j.envsci.2010.11.006

Thoms, C. A. 2008. Community control of resources and the challenge of improving local livelihoods: a critical examination 
of community forestry in Nepal. Geoforum 39(3):1452-1465. http://dx.doi.org/10.1016/j.geoforum.2008.01.006

Tucker, C. M. 2010. Learning on governance in forest ecosystems: lessons from recent research. International Journal of the Commons 4(2):687-706. [online] URL: http://www.thecommonsjournal. org/index.php/ijc/article/view/224.

Tyler, S. R., editor. 2006. Communities, livelihoods and natural resources: action research and policy change in Asia. Intermediate Technology Publications, Warwickshire, UK, and International Development Research Center, Ottawa, Canada.

Wasserman, S., and K. Faust. 1994. Social network analysis: methods and applications. Cambridge University Press, Cambridge, UK. http://dx.doi.org/10.1017/CBO9780511815478

White, D. R., and S. P. Borgatti. 1994. Betweenness centrality measures for directed graphs. Social Networks 16(4):335-346. http://dx.doi.org/10.1016/0378-8733(94)90015-9 
Appendix 1. Complete list (sample) of organizations selected for policy network analysis ( $n=53$ organizational actors; 34 participated in survey).

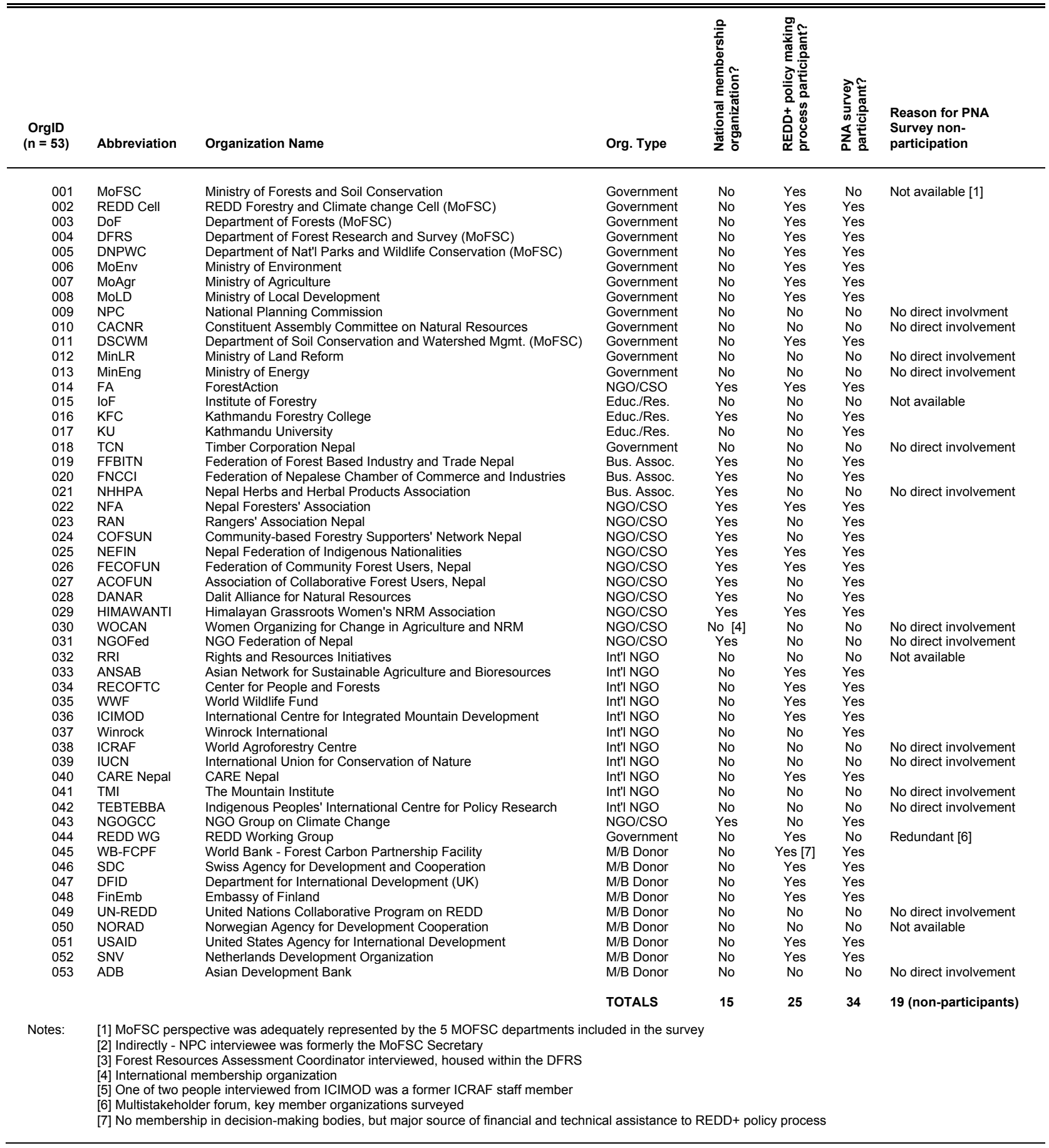


Appendix 2. Network-level measures for perceived influence, information exchange, and collaboration (based on the 34 actors surveyed)

\begin{tabular}{|c|c|c|c|c|}
\hline \multirow[t]{2}{*}{ Measure } & \multirow[t]{2}{*}{ Measure definition } & \multicolumn{3}{|c|}{ Networks } \\
\hline & & $\begin{array}{l}\text { Perceived } \\
\text { influence }\end{array}$ & $\begin{array}{l}\text { Information } \\
\text { exchange }\end{array}$ & Collaboration \\
\hline \multicolumn{5}{|l|}{ Cohesion measures } \\
\hline Number of ties & Total number of ties in network & 486 & 314 & 527 \\
\hline Average degree & $\begin{array}{l}\text { Average number of ties per node } \\
\text { (in/out) }\end{array}$ & 14.29 & 9.24 & 9.94 \\
\hline Density & $\%$ of possible ties existing & 0.43 & 0.28 & 0.35 \\
\hline Reciprocity & $\%$ of pairs with mutual ties & 0.33 & 0.27 & 0.31 \\
\hline $\begin{array}{l}\text { Homophily } \\
\text { (External-internal index) }\end{array}$ & $\%$ of ties among like actors & 0.32 & 0.33 & 0.34 \\
\hline \multicolumn{5}{|c|}{ Centrality measures (centralization and core-periphery) } \\
\hline $\begin{array}{l}\text { In-degree centralization } \\
\text { index }\end{array}$ & $\begin{array}{l}\text { The centrality of the most central } \\
\text { actor compared to the centrality } \\
\text { of all other actors in the network }\end{array}$ & $58 \%$ & $68 \%$ & $51 \%$ \\
\hline $\begin{array}{l}\text { Betweenness } \\
\text { centralization index }\end{array}$ & $\begin{array}{l}\text { Degree to which nodes connect } \\
\text { other actors that are otherwise } \\
\text { not connected }\end{array}$ & $9 \%$ & $21 \%$ & $13 \%$ \\
\hline Core-periphery ratio & $\begin{array}{l}\text { Number of actors in the core vs. } \\
\text { periphery (and } \% \text { in the core) }\end{array}$ & $\begin{array}{l}14 / 20 \\
(41 \%)\end{array}$ & $\begin{array}{l}16 / 18 \\
(47 \%)\end{array}$ & $\begin{array}{l}12 / 22 \\
(35 \%)\end{array}$ \\
\hline
\end{tabular}

